\title{
RANCANG BANGUN SISTEM INFORMASI COMPANY PROFILE DENGAN MENGGUNAKAN METODE SCRUM PADA PT. HASNA SATYA NEGARA BERBASIS WEB
}

\author{
Design and Build Company Profile Information System Using Scrum Method At PT. \\ Hasna Satya Negara WEB-Based \\ Try Setya Nugraha*1, Kusnadi ${ }^{2}$, Rifqi Hardian ${ }^{3}$ \\ 1,2,3 Teknik Informatika, Fakultas Teknologi dan Informasi, Universitas CIC \\ e-mail: *1trysetya20@gmail.com, ${ }^{2}$ kusnadi@cic.ac.id, ${ }^{3}$ rifqifhrdn@gmail.com
}

\begin{abstract}
Abstrak
PT. Hasna Satya Negara adalah bentuk PT dari Hasna Group, PT ini bergerak dalam bidang Developer Property yang terfokus dengan pengembangan dan pembangunan perumahan. Produk dari Hasna Group berupa perumahan bersubsidi maupun non-subsidi sehingga dapat membantu masyarakat dalam mewujudkan impian memiliki rumah dengan subsidi yang disediakan oleh pemerintah. Banyak kendala yang terjadi saat Hasna Group melakukan penyebaraan informasi karena masih dilakukan secara manual yaitu menyebar beberapa brosur di tempat umum, kendala yang terjadi meliputi, terbatasnya karyawan yang melakukan penyebaran, bertambahnya biaya yang dikeluarkan untuk membuat brosur dan ongkos untuk melakukan penyebaran brosur, menggunakan banyak kertas sehingga bertambahnya biaya operasional. Sistem Informasi Company Profile merupakan sebuah sistem berbasis web yang menyediakan layanan berupa informasi yang dapat memecahkan masalah pada perusahaan dan menghasilkan sebuah alternatif untuk menyediakan layanan informasi sekaligus menjadikan media untuk periklanan digital. Metode Agile adalah suatu metode pola pikir untuk menyelesaikan permasalahan yang bersifat flexible terhadap perubahan suatu masalah, sehingga pola penyelesaian masalah menggunakan metode agile menyesuaikan perubahan. Pendekatan Scrum merupakan pencapaian terbesar dalam menerapkan metode Agile, dengan Scrum sifat-sifat itu diwujudkan menjadi sebuah langkah-langkah. Berdasarkan analisis yang sudah dilakukan dan terdapatnya masalah - masalah yang ada, Hasna Group dapat mengimplementasikan sebuah sistem informasi company profile berbasis web menggunakan metode agile dengan pendekatan scrum.
\end{abstract}

Kata Kunci: Sistem Informasi, Company Profile, Metode Scrum.

\begin{abstract}
PT. Hasna Satya Negara is a form of PT from the Hasna Group, this PT is engaged in Property Developer which focuses on housing development and construction. Products from the Hasna Group are subsidized and non-subsidized housing so that they can help people realize their dreams of owning a house with subsidies provided by the government. Many obstacles occurred when Hasna Group disseminated information because it was still done manually, namely distributing several brochures in public places, the obstacles that occurred included limited employees who carried out distribution, increased costs incurred to make brochures and costs for distributing brochures, using a lot of paper, thereby increasing operational costs. Company Profile Information System is a web-based system that provides services in the form of information that can solve problems in the company and produce an alternative for providing information services as well as making media for digital advertising. Agile method is a mindset method to solve problems that are flexible to changes in a problem, so that problem solving patterns using agile methods adjust to changes. The Scrum approach is the greatest achievement in applying Agile methods, with Scrum the properties are translated into steps. Based on the analysis that has been done and the problems that exist, Hasna Group can implement a web-based company profile information system using the agile method with the scrum approach.
\end{abstract}

Keywords: Informatics System, Company Profile, Scrum Methode

Informasi Artikel:

Submitted: Oktober 2021, Accepted: Oktober 2021, Published: November 2021

ISSN: 2685-4902 (media online), Website: http://jurnal.umus.ac.id/index.php/intech 


\section{PENDAHULUAN}

PT adalah salah satu jenis badan usaha yang dilindungi oleh hukum dengan modal yang terdiri dari saham. Seseorang dikatakan sebagai pemilik PT apabila memiliki bagian saham sebesar dari jumlah yang ditanamkannya. Badan hokum yang bertujuan untuk mengejar kepentingan ekonomi adalah PT [1]. PT. Hasna Satya Negara adalah Perseroan Terbatas yang bergerak di bidang properti dan Developing Perumahan. Perusahan ini merupakan perusahaan independent yang bergerak sejak 2014. Property developer merupakan bisnis legalitas karena seluruh aktifitas developer mulai dari membeli tanah sampai dengan membangun dan pemasaran proyek bersinggungan dengan peraturan, baik berupa undang-undang, peraturan pemerintah, peraturan menteri dan peraturan daerah. Skema proses bisnis perusahaan developer perumahan dirancang dengan melakukan competitive benchmarking yang lebih unggul [2]. Penyebaran informasi yang dilakukan oleh PT. Hasna Satya Negara masih melakukan dengan cara yang manual yaitu melakukan penyebaran brosur di tempat umum sehingga dapat menambah biaya operasional untuk melakukan penyebaran penyebaran informasi tersebut, biaya operasional yang dikeluarkan oleh PT. Hasna Satya Negara meliputi, pembelian kertas, pembelian tinta printer, pembelian bahan bakar untuk kendaraan yang digunakan oleh karyawan. Pengeluaran - pengeluaran tersebut dapat PT. Hasna Satya Negara persempit dengan cara memberhentikan penyebaran informasi tersebut secara manual dan beralih menggunakan layanan penyedia informasi. Media informasi merupakan alat untuk mengumpulkan dan menyusun kembali sebuah informasi sehingga menjadi bahan yang bermanfaat bagi penerima informasi. Informasi merupakan bagian yang medsar dalam pengetahuan yang terdidik dan pemberdayaan dalam berpartisipasi dalam pembangunan social dan kemajuan [3].

Suatu perusahaan khususnya perusahaan yang bergerak dalam bidang properti tentunya melakukan penyebaran suatu informasi berupa iklan kepada kalayak umum demi kebutuhan promosi agar produk-produk yang ditawarkan bisa dikenal oleh masyarakat umum. Iklan adalah berita atau pesan untuk mendorong, membujuk khalayak ramai agar tertarik pada barang dan jasa yang ditawarkan. Pemberitahuan kepada khayalak mengenai barang atau jasa yang dijual, dipasangdi dalam media massa atau di tempat umum[4]. Company profile merupakan bentuk media informasi dan alat untuk perusahaan memberikan gambaran mengenai perusahaan itu sendiri, company profile dijadikan alat dan media promosi atau media marketing untuk dapat menjangkau lebih banyak dan luas wilayah mendapatkan customer baru [5]. Metode yang akan membantu penulis dalam membangun suatu perancangan Sistem Informasi ini adalah metode Scrum. Metode Scrum merupakan suatu metodologi atau kerangka kerja yang terstruktur untuk pengembangan produk yang kompleks. Scrum menggunakan pendekatan yang bertahap dan berkelanjutan untuk mengoptimalkan kemampuan prediksi dan mengendalikan risiko[6]. Kelebihan dari menggunakan metode scrum adalah karena sebuah metode scrum adalah metode yang mudah dikontrol, fleksibel, memuat strategi pengembangan menyeluruh dimana seluruh tim bekerja sebagai satu unit untuk mencapai goal yang sama. Selain itu, dapat memberikan kepuasan optimal dalam penyelesaian permintaan [7].

Permasalahan yang biasa menimpa sebuah perusahaan adalah masyarakat kurang mengenal terhadap produk-produk yang ditawarkan, maka konsep yang diambil dari tugas akhir ini adalah membangun Sistem Informasi berupa company profile untuk PT. Hasna Satya Negara yang bukan hanya memberikan informasi kepada masyarakat tetapi juga dapat memvisualisasikan secara atraktif dan menarik, dengan mengambil judul "Rancang Bangun Sistem Informasi Company Profile Dengan Menggunakan Metode Scrum Pada PT. Hasna Satya Negara Berbasis WEB." 


\section{METODE PENELITIAN}

\section{Metode Agile}

Metode scrum pada dasrnya mengutamakan pada kecepatan dan fleksibilitas pengembangan proyek lunak [8]. SCRUM adalah salah satu metode rekayasa perangkat lunak dengan menggunakan prinsip-prinsip pendekatan AGILE, yang bertumpu pada kekuatan kolaborasi tim, incremental product dan proses iterasi untuk mewujudkan hasil akhir. Kelebihan dari menggunakan metode scrum adalah karena sebuah metode scrum adalah metode yang mudah dikontrol, fleksibel. Scrum pada DSD dapat membrrikan hasil positif dalam komunikasi dan dapat terdistribusikan lebih sering dan benar [9]. Kekurangan metode ini adalah tidak cocok untuk dikerjakan oleh tim dalam jumlah skala besar ( $>20$ anggota tim). Tidak diperkenankan adanya perubahan siklus pengembanan dan membutuhkan waktu yang lama [10]. Scrum membantu Anda untuk mengorganisir sebuah tim dan Anda harus memiliki komunikasi yang kuat antar member tim tersebut. Scrum mengatakan bahwa setiap "sprint" dimulai dengan meeting singkat untuk perencanaan dan diakhiri dengan review. Ini adalah ide fundamental dari Scrum untuk sebuah project management. Agile adalah seperangkat "metode dan praktik berdasarkan nilai dan prinsip yang diungkapkan dalam Agile Manifesto_," yang mencakup halhal seperti kolaborasi, pengorganisasian yang dilakukan sendiri oleh member tim, dan tim yang lintas fungsional. Scrum adalah kerangka kerja yang digunakan untuk mengimplementasikan pengembangan Agile, Scrum dapat membantu Anda mengatur tim Anda dan menyelesaikan lebih banyak pekerjaan dalam waktu yang lebih singkat.

\section{Tahapan Metode Agile Product Backlog}

Bagian pertama ini adalah kumpulan dari hal-hal yang diperlukan dan yang harus tersedia dalam produk. Produk backlog berada dalam tanggung jawab product owner.Product Backlog adalah daftar utama dari semua fungsi yang diinginkan dalam produk. Metode Scrum tidak mewajibkan dokumentasi semua persyaratan pada awal proyek.

Sprint Backlog

Perencanaan Sprint dilakukan dalam pertemuan atau meeting antara product owner dan tim developer yang akan bekerja sama untuk memilih product backlog untuk dimasukan ke dalam proses sprint. Hasil dari pertemuan tersebut yaitu Sprint Backlog.

\section{Sprint}

Sprint merupakan suatu kerangka waktu yang berdurasi paling lama 1 bulan untuk mengembangkan produk yang akan dirilis. Di dalam Sprint terdapat 2 bagian pekerjaan :

Pertemuan Harian (Daily Standup Meeting)

Merupakan pertemuan dimana setiap 24 jam (1 hari), tim pengembangan bertemu untuk membahas proses pengembangan produk.

Refleksi Sprint

Merupakan pertemuan yang dilakukan setiap bulannya, yang bertujuan untuk membahas hal dari Sprint Backlog yang telah berjalan dan telah berhasil dikerjakan, serta dapat memperbaiki dan meningkatkan kualitas produk pada Sprint yang berikutnya.

\section{Review \& Retrospective}

Review \& Retrospective adalah hasil dari Product Backlog yang sudah selesai dikerjakan pada Sprint. Di akhir Sprint, Review \& Retrospective harus sudah benar-benar selesai, yang berarti harus dalam keadaan yang useable. 


\section{HASIL DAN PEMBAHASAN}

Pada bagian ini akan dijelaskan Pengelompokan Kebutuhan Berdasarkan Metode Agile. Dalam Metode Agile terdapat kebutuhan customer sehingga tercapainya sebuah sistem berdasarkan tabel kebutuhan user/customer. Sebelum melangkah menuju penyelesaian dengan menggunakan metode Agile, untuk lebih detail dalam mengelompokan kebutuhan user sebaiknya membuat tabel prioritas, tabel kelompok kerja sistem dan tabel kebutuhan fungsional terlebih dahulu, setelah terkumpuulnya data kebutuhan user dan terkumpulnya data kebutuhan prioritas sistem dan kelompok kerja sistem, maka kita dapat masuk kedalam proses Metode Scrum yang pertama yaitu menentukan Product Backlog.

Setelah terwujudnya Product Backlog, maka akan dilanjutkan keproses penentuan Sprint Backlog lalu melakukan Sprint, setelah melakukan sprint makan dibuatlah sebuah Review and Retrospective.

Membuat Tabel Prioritas Kebutuhan.

Tabel 1. Tabel Tingkat Prioritas Kebutuhan

\begin{tabular}{ccc}
\hline No & Penentuan Prioritas & Keterangan \\
\hline $\mathbf{1}$ & Sangat Penting & Pengerjaan didahulukan. \\
\hline $\mathbf{2}$ & Penting & dilakukan setelah selesai prioritas \\
& & sangat penting. \\
\hline
\end{tabular}

Membuat Tabel Kelompok Kerja Sistem.

Tabel 2. Kerja Sistem Manajemen Data

\begin{tabular}{|c|c|c|}
\hline No & Kerja Sistem & Bagian Kerja Sistem \\
\hline \multirow[t]{8}{*}{1} & \multirow[t]{8}{*}{ Manajemen Data } & Membuat Database \\
\hline & & Membuat Halaman Login Admin \\
\hline & & Membuat Halaman Dashboard Admin \\
\hline & & Membuat Fitur Kelola Profile Admin \\
\hline & & Membuat Fitur Kelola Product \\
\hline & & Membuat Fitur Kelola Email Newsletter \\
\hline & & Membuat Fitur Kelola Berita \\
\hline & & Membuat Fitur Kelola Kotak Masuk \\
\hline \multicolumn{3}{|c|}{ Tabel 3. Kerja Sistem Manajemen Data } \\
\hline \multirow{4}{*}{\multicolumn{2}{|c|}{1 Manajemen Data }} & Membuat Fitur Kelola Brosur \\
\hline & & Membuat Fitur Kelola Gallery \\
\hline & & Mengupload project ke hosting \\
\hline & & Mentautkan project didalem hosting ke domain \\
\hline \multicolumn{3}{|c|}{ Tabel 4. Tabel Kerja Sistem User Interface } \\
\hline No & Kerja Sistem & Bagian Kerja Sistem \\
\hline \multirow[t]{5}{*}{1} & \multirow[t]{5}{*}{ User Interface } & Membuat halaman utama Hasna Group \\
\hline & & Membuat halaman About Us Hasna Group \\
\hline & & Membuat halaman Gallery Hasna Group \\
\hline & & Membuat halaman Contact Hasna Group \\
\hline & & Membuat sitemap Hasna Group \\
\hline
\end{tabular}




\begin{tabular}{|c|c|}
\hline No $\quad$ Kerja Sistem & Bagian Kerja Sistem \\
\hline & Membuat halaman utama Product 1 \\
\hline & Membuat halaman About Us Product1 \\
\hline & Membuat halaman Gallery Product 1 \\
\hline & Membuat sitemap Product 1 \\
\hline & Membuat halaman utama Product 2 \\
\hline & Membuat halaman About Us Product 2 \\
\hline & Membuat halaman Gallery Product 2 \\
\hline & Membuat sitemap Product 2 \\
\hline Tabel 5 Tab & el Kerja Sistem User Interface Lanjutan \\
\hline \multirow[t]{4}{*}{1 User Interface } & Membuat halaman utama Product 3 \\
\hline & Membuat halaman About Us Product 3 \\
\hline & Membuat halaman Gallery Product 3 \\
\hline & Membuat sitemap Product 3 \\
\hline
\end{tabular}

Membuat Tabel Kebutuhan Fungsional Sistem

Tabel 6. Kebutuhan Manajemen Data

\begin{tabular}{|c|c|c|c|}
\hline No & & Deskripsi & Priority \\
\hline 1 & \multirow[t]{9}{*}{ Sistem } & Sistem dapat menampilkan halaman login & Sangat Penting \\
\hline 2 & & Sistem dapat menampilkan halaman dashboard & Penting \\
\hline 3 & & Sistem dapat menampilkan halaman kelola product & Sangat Penting \\
\hline 4 & & Sistem dapat menampilkan halaman kelola email newsletter & Sangat Penting \\
\hline 5 & & Sistem dapat menampilkan halaman kelola testimoni & Sangat Penting \\
\hline 6 & & Sistem dapat menampilkan halaman halaman Kelola Berita & Sangat Penting \\
\hline 7 & & Sistem dapat menampilkan halaman kelola kotak masuk & Sangat Penting \\
\hline 8 & & Sistem dapat menampilkan halaman kelola brosur & Sangat Penting \\
\hline 9 & & Sistem dapat menampilkan halaman kelola data gellery & Sangat Penting \\
\hline & \multicolumn{3}{|c|}{ Tabel 7. Kebutuhan Fungsional Pengunjung } \\
\hline No & & Deskripsi & Priority \\
\hline 1 & \multirow[t]{5}{*}{ Pengunjung } & User dapat mengunjungi halaman utama Hasna Group & Sangat Penting \\
\hline 2 & & User dapat melakukan subscribe email untuk newsletter & Sangat Penting \\
\hline 3 & & User dapat melakukan fitur contact support & Sangat Penting \\
\hline 4 & & User dapat mengunjungi halaman utama Produk 1 & Sangat Penting \\
\hline 5 & & User dapat mengunjungi halaman utama Produk 2 & Sangat Penting \\
\hline
\end{tabular}


Tabel 8. Kebutuhan Fungsional Pengunjung Lanjutan

\begin{tabular}{|c|c|c|c|}
\hline 6 & Pengunjung & User dapat mengunjungi halaman utama Produk 3 & Sangat Penting \\
\hline 7 & & $\begin{array}{l}\text { User dapat menggunakan fitur lihat berita pada tiap } \\
\qquad \text { produk }\end{array}$ & Penting \\
\hline 8 & & $\begin{array}{l}\text { User dapat menggunakan fitur lihat gallery pada tiap } \\
\text { produk }\end{array}$ & Penting \\
\hline 9 & & $\begin{array}{l}\text { User dapat menggunakan fitur lihat about us pada tiap } \\
\text { produk }\end{array}$ & Penting \\
\hline 10 & & $\begin{array}{l}\text { User dapat menggunakan fitur download brosur pada } \\
\text { tiap produk }\end{array}$ & Penting \\
\hline
\end{tabular}

Menentukan Product Backlog

Tabel 9. Tabel Product Backlog No Backlog Item Website Company Profile PT. Hasna Satya Negara

1. Sebagai Developer, saya ingin menyelesaikan kerja sistem manajemen data.

2. Sebagai Developer, saya ingin menyelesaikan kerja sistem User Interface.

3. Sebagai admin, saya ingin memastikan bahwa sistem manajemen data dapat berfungsi.

Tabel 10. Tabel Product Backlog Lanjutan

4. Sebagai admin, saya ingin meastikan bahwa sistem user interface dapat tampil sesuai pengelompokan.

Menentukan Sprint Backlog.

Tabel 11. Tabel Sprint Backlog Sprint Backlog Pada Website Company Profile PT. Hasna Satya Negara

\begin{tabular}{clc}
\hline No & Story & $\begin{array}{c}\text { Estimate } \\
\text { (Days) }\end{array}$ \\
\hline $\mathbf{1}$ & Menyelesaikan kerja sistem manajemen Data & 40 \\
\hline $\mathbf{2}$ & Menyelesaikan kerja sistem User Interface & 40 \\
\hline $\mathbf{3}$ & $\begin{array}{l}\text { Memastikan berfungsi nya sistem berdasarkan tabel } \\
\text { fungsional }\end{array}$ & 5 \\
\hline $\mathbf{4}$ & $\begin{array}{l}\text { Memastikan berfungsi nya sistem berdasarkan tabel } \\
\text { non-fungsional }\end{array}$ & 5 \\
\hline
\end{tabular}

Melakukan Sprint.

Tabel 12. Sprint I

\begin{tabular}{|c|c|c|c|}
\hline Tahap & Start & Days & End \\
\hline Sprint 1 & $05-02-2021$ & 40 & $06-12-2021$ \\
\hline \multicolumn{4}{|c|}{ Menyelesaikan halaman dari tabel kerja sistem manajemen data } \\
\hline \multicolumn{4}{|c|}{ Tabel 13. Sprint II } \\
\hline Tahap) & Start & Days & End \\
\hline Sprint 2 & 06-13-2021 & 40 & 07-23-2021 \\
\hline
\end{tabular}


Tabel 14. Sprint III

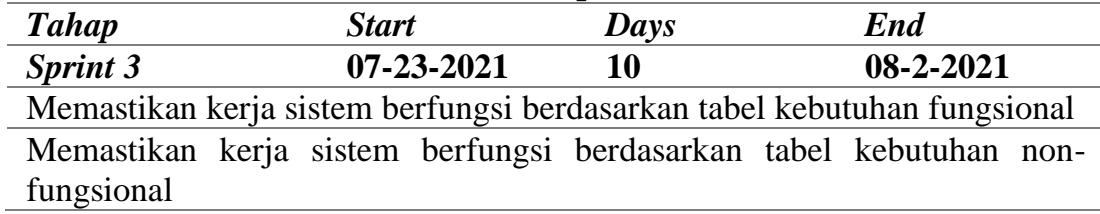

Menentukan Review and Retrospective

Tabel 15. Retrospective I

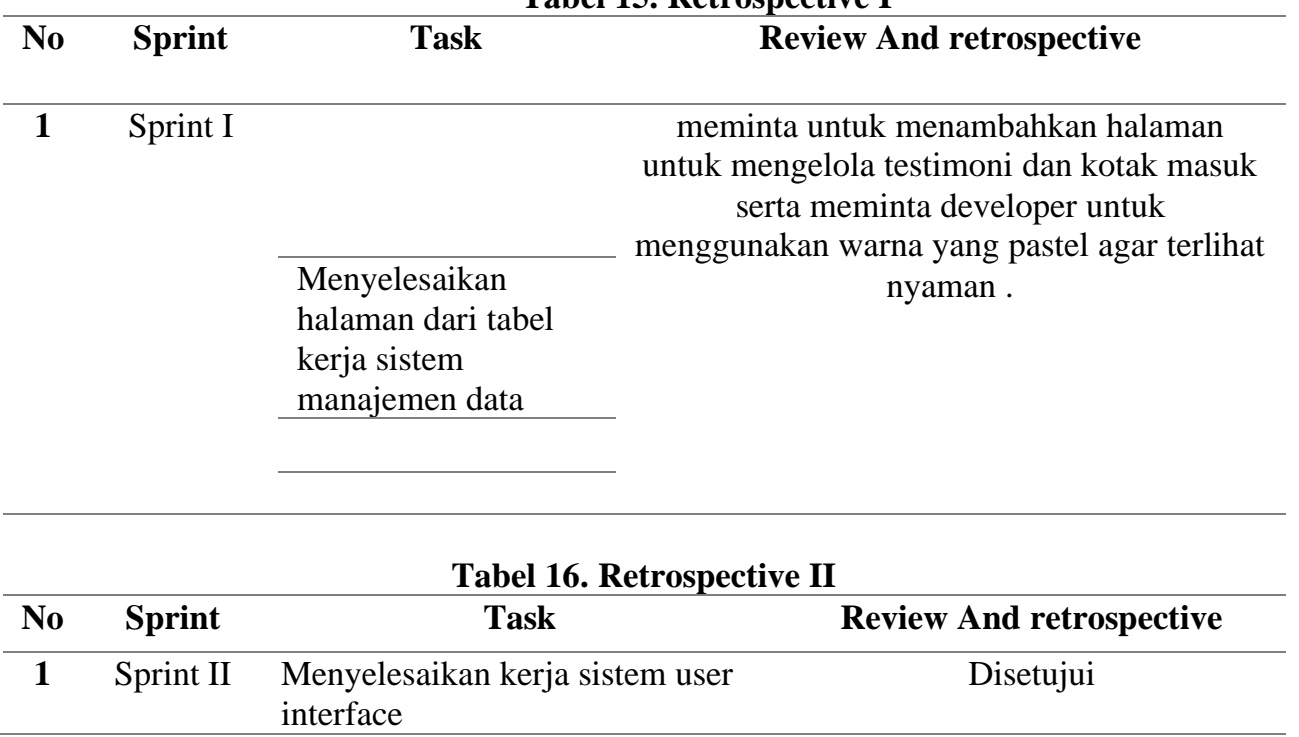

Tabel 17. Retrospective III

\begin{tabular}{cclc}
\hline No & Sprint & \multicolumn{1}{c}{ Task } & Review And retrospective \\
\hline $\mathbf{1}$ & Sprint III & $\begin{array}{l}\text { Memastikan berfungsinya sistem } \\
\text { berdasarkan tabel fungsional }\end{array}$ & Berfungsi \\
\hline $\mathbf{2}$ & Sprint III & $\begin{array}{l}\text { Memastikan berfungsinya sistem } \\
\text { berdasarkan tabel non-fungsional }\end{array}$ & Berfungsi \\
\hline
\end{tabular}

Implementasi Pengujian Metode Agile

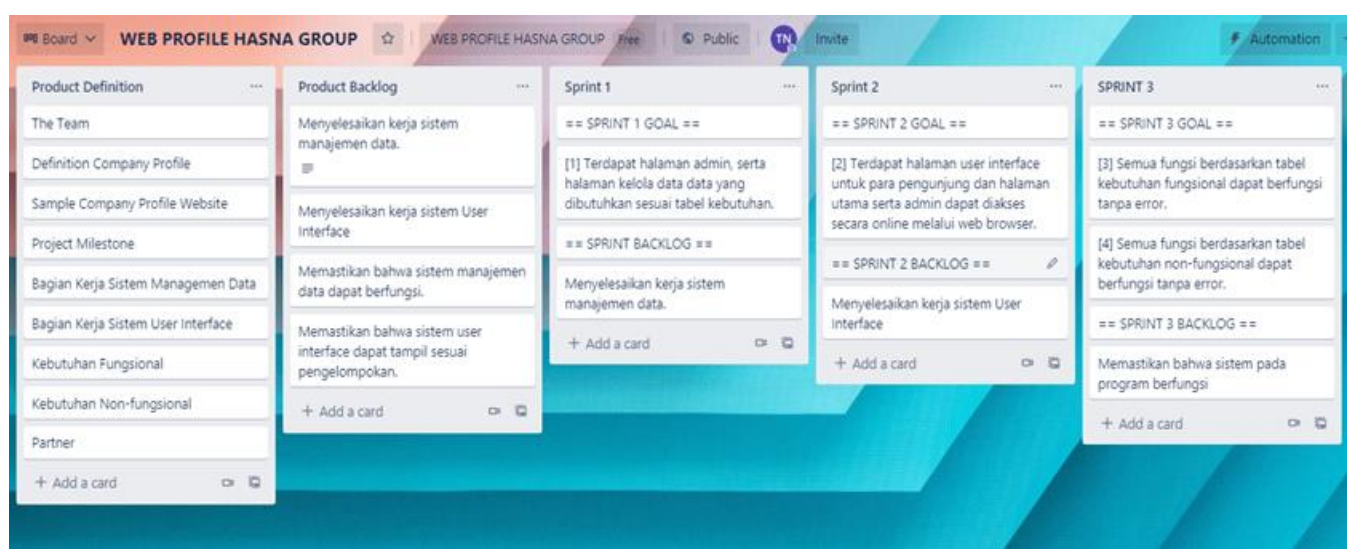

Gambar 1. Implementasi Scrum Pada Aktifitas Pembuatan Sistem Informasi 


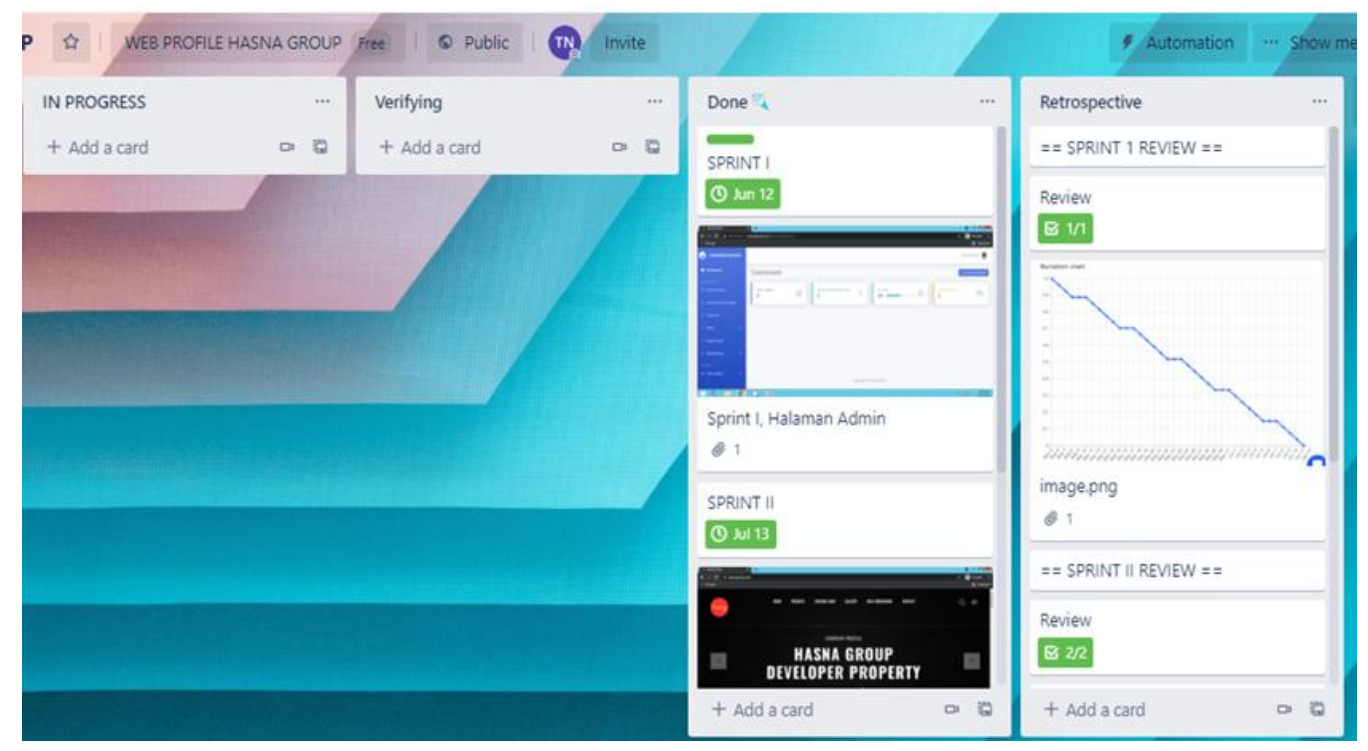

Gambar 2. Implementasi Scrum Pada Aktifitas Pembuatan Sistem Informasi Lanjutan

\section{KESIMPULAN}

Berdasarkan hasil implementasi dan pengujian Sistem Informasi Company Profile pada PT. Hasna Satya Negara Berbasis WEB, dapat disimpulkan bahwa. Belum tersedianya sistem informasi yang menyediakan beberapa informasi secara mendetail tentang perusahaan Hasna Group dan beberapa produknya, maka metode Agile dengan pendekatan scrum adalah salah satu metode yang dapat memberikan solusi yang dapat menyelesaikan dari permasalahan tersebut. Dengan adanya pendekatan Agile dan dengan pelaksanaan nya metode scrum dapat menghasilkan sebuah sistem yang menyediakan sebuah layanan informasi sesuai dengan kebutuhan fungsional dan non-fungsional dari PT. Hasna Satya Negara. Dalam sistem ini, yang ditonjolkan adalah penyampaian media informasi detail secara online, sehingga calon customer mendapatkan informasi tersebut dengan mudah karena dapat diakses secara online.

\section{UCAPAN TERIMA KASIH}

Banyak - banyak kata Terimakasih dan syukur saya panjatkan kepada Tuhan YME atas berhasilnya jurnal penelitian yang saya buat sehingga dapat tercapainya tujuan penelitian yang menjadi tujuan awal saya membuat penelitian. Tidak luput saya panjatkan banyak Terimakasih kepada Institusi Univisersitas Catur Insan Cendikia atas dukungan moril serta dukungan Finansial terhadap penelitian yang telah saya buat. Teruntuk keluarga, teman, saudara dan kerabat lainya yang telah ikut serta berpartisipasi dalam terwujudnya penelitian yang saya buat, saya ucapkan banyak - banyak terimakasih.

\section{DAFTAR PUSTAKA}

[1] V. T. Wahyuni, "Kepemilikan Tunggal Badan Hukum Perseroan Terbatas (PT)," J. Huk. Nov., vol. 8, no. 2, p. 201, 2017, doi: 10.26555/novelty.v8i2.a6914.

[2] A. Aisyati dan Wisdania Rusdianasito, "Perancangan Sistem Manajemen Perusahaan Pengembang Perumahan CV. ABC," Perfoma, vol. 11, no. 2, pp. 95-106, 2012, [Online]. Available: https://jurnal.uns.ac.id/performa/article/download/13930/11586.

[3] D. Suri, "Pemanfaatan Media Komunikasi dan Informasi dalam Perwujudan 
Pembangunan Nasional," J. Komun. Pembang., vol. 17, no. 2, pp. 177-187, 2019, doi: $10.46937 / 17201926848$.

[4] I. G. A. D. A. Dewi, "Makna Kiasan Visual Dalam Iklan Minuman Kaleng Beralkhol Suntory 'Strong Zero,"' J. Pendidik. Bhs. Jepang Undiksha, vol. 6, no. 3, p. 294, 2020, doi: 10.23887/jpbj.v6i3.25798.

[5] S. F. Monica, "Company Profile Berrbasis Web pada PT. Bintang Engergi Sejahtera," Surabaya, 2021. [Online]. Available: https://emea.mitsubishielectric.com/ar/productssolutions/factory-automation/index.html.

[6] W. Warkim, M. H. Muslim, F. Harvianto, and S. Utama, "Penerapan Metode SCRUM dalam Pengembangan Sistem Informasi Layanan Kawasan," J. Tek. Inform. dan Sist. Inf., vol. 6, no. 2, pp. 365-378, 2020, doi: 10.28932/jutisi.v6i2.2711.

[7] I. A. Paramitha, "Tinjauan Pustaka Tinjauan Pustaka," 2017. [Online]. Available: https://rachmat.id/articles/kelebihan-dan-kekurangan-scrum.

[8] H. R. Suharno, N. Gunantara, and M. Sudarma, "Manajemen Proyek Dalam Industri \& Organisasi Digital," Maj. Ilm. Teknol. Elektro, vol. 19, no. 2, 2020, doi: http://doi.org/10.24843/MITE.2020.v19i02.P12.

[9] R. A. Azdy and A. SN, "Implementasi Scrum Pada Pengembangan Software Terdistribusi," Semin. Nas. Inform. 2012, vol. 1, no. 2, pp. 32-37, 2012.

[10] Juma'atin, "Pengembangan Media Pembelajaran Berbentuk Jam Sudut untuk Meningkatkan Hasil Belajar Siswa Materi Pengukuran Sudut Mata Pelajaran Matematika Kelas IV di MI Miftahul Huda Karangploso,” 2018. [Online]. Available: http://journals.sagepub.com/doi/10.1177/1120700020921110\%0A. 